\title{
PENGARUH KOMPETISI DALAM E-PROCUREMENT TERHADA NILAI PENAWARAN PEMENANG ATAS BELANJA PEMERINTAH: STUDI EMPIRIS PADA LAYANAN PENGADAAN SECARA ELEKTRONIK KOTA TANJUNGPINANG
}

\author{
Budi Zulfachri \\ Sekolah Tinggi Ilmu Ekonomi (STIE) Pembangunan Tanjungpinang \\ zulfachri@stie-pembangunan.ac.id \\ Ranti Utami \\ Sekolah Tinggi Ilmu Ekonomi (STIE) Pembangunan Tanjungpinang \\ ranti@stie-pembangunan.ac.id
}

\begin{abstract}
Abstrak. Penelitian ini bertujuan untuk mengetahui pengaruh kompetisi dalam $e$-procurement terhadap nilai penawaran pemenang atas belanja pemerintah pada Layanan Pengadaan Secara Elektronik (LPSE) Kota Tanjungpinang. Kompetisi dalam pengadaan ini yaitu jumlah peserta, nilai pekerjaan dan lama waktu pekerjaan tender dengan menggunakan model e-lelang pemilihan langsung. Data dalam penelitian ini adalah data 34 tender yang diperoleh dari web Layanan Pengadaan Secara Elektronik (LPSE) dan Kantor Unit Layanan Pengadaan (ULP) Kota Tanjungpinang. Teknis analisis data dalam penelitian ini adalah regresi linear untuk menganalisis pengaruh individual variabel terhadap nilai penawaran pemenang. Analisis varians dalam penelitian ini untuk menguji secara simultan pengaruh seluruh variabel terhadap nilai penawaran pemenang. Pengolahan data menggunakan dalam penelitian menggunakan JASP (Jeffreys's Amazing Statistics Program.) versi 0.14.10. Hasil penelitian didapat bahwa nilai signifikan $\mathrm{F}=0,004<$ 0,50 . Hasil uji koefisien determinasi untuk keseluruhan variabel didapat nilai $R$ Square yang diperoleh sebesar 0,36 atau $36 \%$ dan sisanya $64 \%$ dipengaruhi oleh variabel lain yang tidak diteliti dalam penelitian ini. dengan persamaan regresi $\mathrm{Y}=94,64-0,145 x_{1}-0,003 x_{2}+0,049 x_{3}+e$. Hasil penelitian menunjukkan bahwa jumlah peserta dan nilai pekerjaan tender berpengaruh negatif terhadap nilai penawaran pemenang sedangkan lama waktu pekerjaan tender berpengaruh positif terhadap nilai penawaran pemenang. Semua variabel secara simultan berpengaruh terhadap nilai penawaran pemenang.
\end{abstract}

Kata Kunci: Kompetisi, e-procurement, pengadaan, belanja pemerintah, penawaran pemenang

\begin{abstract}
The purpose of this study is for finding the influence of competition in e-procurement on the bid value of winning bidder for government expenditure in the Electronic Procurement Services of Tanjungpinang City. The competition in this e-procurement is about the number of bidders, tender value and tender period, by using direct election model of e-tendering. The research used data of 34 tenders which were obtained from the website of Tanjungpinang Electronic Procurement Services and Procurement Services Unit Office. The data was analysed by using a linear regression technic to find the effect of individual variable on the bid value of winning bidder. Meanwhile, the variance of analysis in this study is for examining the influence of all variables on the winner's bidding simultaneously. Data processing using the research using JASP (Jeffreys's Amazing Statistics Program.) Version 0.14.10. The estimation was resulted in a significant value of $F=0,004<0,50$. The coefficient of determination test for all variables generated Adjusted $R$ squared that is 0,36 or
\end{abstract}


$36 \%$ and the rest of $64 \%$ was impacted by other variables which were not studied in this research, by applying the regression equation $Y=94,646-0,145_{1}-0,003 x_{2}+0,049 x_{3}+e$. The result of this study showed that the number of bidders and the value of tender negatively affected the bidding value from a winner, while the length of tender period gave a positive impact on the winner's bid price. All variables simultaneously influence the offered value of winning bidder.

Keywords: Competition, e-procurement, procurement, government expenditure, winner's bidding

\section{PENDAHULUAN}

Semakin berkembangnya era globalisasi di Indonesia, semakin canggih pula teknologi yang ada didalamnya. Saat ini memasuki era disrupsi teknologi yang mana telah menjadi bagian dari seluruh aktivitas, yaitu fenomena Internet of Thing, big data, cloud computing hingga artificial intelegent. Dengan hal itu dapat menciptakan model teknologi baru dengan menggunakan strategi yang lebih inovatif dan disruptif. Selain itu disruptif teknologi menuntut untuk berinovasi atau tertinggal. Publik diharuskan untuk membuat hal baru atau create dan mampu membentuk ulang atau reshape. Dengan kata lain, harus mampu berusaha serta berani untuk menciptakan sebuah inovasi atau memperbaharui dengan inovasi dari produk atau layanan yang sudah dimiliki. Perkembangan teknologi mengakibatkan terjadinya kemajuan yang signifikan terhadap setiap lini kehidupan termasuk dalam pengadaan barang dan jasa, yang sebelumnya pengadaan barang dan jasa ini dilakukan dengan metode tawar-menawar langsung hingga kemudian akan mencapai kesepakatan harga.

Dalam proses tawar-menawar tersebut biasanya memakan waktu yang cukup lama apalagi jika melakukan pembelian dalam jumlah barang atau jasa yang banyak sehingga akan membuat pengguna membuat daftar jenis barang atau jasa yang akan dibeli secara manual (tertulis) dan setelah itu diserahkan kepada penyedia barang atau jasa. Ini merupakan asal-usul dokumen penawaran yang disusun secara tertulis.

Menurut (Peraturan Presiden Republik Indonesia No.16 Tentang Pengadaan Barang / Jasa Pemerintah, 2018) Dalam Bab I Ketentuan Umum Pasal 1 ayat 1 tentang Pengadaan Barang atau Jasa Pemerintah disebutkan bahwa Pengadaan Barang/ Jasa Pemerintah yang selanjutnya disebut Pengadaan Barang/ Jasa adalah kegiatan Pengadaan Barang/ Jasa oleh Kementerian/ Lembaga/ Perangkat Daerah yang dibiayai oleh APBN/ APBD yang prosesnya sejak identifikasi kebutuhan, sampai dengan serah terima hasil pekerjaan. Perencanaan pengadaan meliputi identifikasi kebutuhan, penetapan barang/jasa, cara, jadwal, dan anggaran Pengadaan Barang/ Jasa.

Dengan adanya peraturan ini, Pengadaan Barang/ Jasa Pemerintah pun semakin dituntut membuat kebijakan Pengadaan 
Barang/ jasa untuk memberikan value for money (menghasilkan barang/ jasa yang tepat dari setiap uang yang dibelanjakan, diukur dari aspek kualitas, banyaknya jumlah barang, lamanya waktu dalam pengerjaan tender, alokasi biaya, dan penyedia), meningkatkan penggunaan produk dalam negeri, meningkatkan peran serta usaha (mikro, kecil, dan menengah), meningkatkan peran perusahaan nasional, meningkatkan pemanfaatan barang/ jasa hasil penelitian dan industri kreatif, mendorong pemerataan ekonomi, dan mendorong pengadaan berkelanjutan. Pengadaan Barang/ Jasa harus menjadi lebih sederhana, tidak berbelit-belit agar mudah di cek, diawasi serta dikontrol.

Pratik pengadaan barang/ jasa tidak terlepas dari adanya penyimpangan antara pejabat pemerintahan dengan perusahaan yang memenangkan tender. Dalam beberapa tahun terakhir, tuntutan publik terhadap efisiensi atas belanja pemerintah menunjukkan peningkatan yang signifikan.

Ternyata tuntutan tersebut bukan hanya tuntutan nasional melainkan merupakan tuntutan global yang timbul karena besarnya uang Negara yang digunakan dalam proses Pengadaan Barang/ Jasa atas belanja pemerintah dan faktanya bahwa uang tersebut berasal dari rakyat. Dengan adanya sistem e-procurement yang diterapkan di Indonesia, diharapkan agar hal-hal yang bersifat korupsi dan kolusi dapat diminimalisir agar tidak terjadi kebocoran keuangan Negara. Pemerintah telah menetapkan agar semua Kementrian dan Pemerintah Daerah harus mematuhi untuk melakukan pengadaan melalui mekanisme $e$ procurement atau dengan kata lain merupakan proses pembelian Barang/ Jasa secara elektronik. Indonesia telah melaksakan proses pembelian atau melaksanakan proyek publik dengan cara elektronik (e-procurement) sejak tahun 2008 berdasarkan dari Keputusan Presiden.

Di indonesia, publik menutut pemerintah untuk mengupayakan 4 efiseinsi terhadap belanja pemerintah, karena didorong oleh anggapan bahwa tingkat kebocoran keuangan Negara yang terjadi dalam pengadaan barang/ jasa sangat tinggi. Anggapan tersebut berdasarkan dengan banyaknya kasus korupsi pada proses pengadaan barang/ jasa yang melibatkan pejabat pemerintahan dan perusahaan yang terlibat. Indonesia Corruption Watch (ICW) mencatat sepanjang tahun 2017 sedikitnya ada sekitar 84 kasus korupsi dalam sektor Pengadaan Barang dan Jasa (PBJ) yang diproses oleh aparat penegak hukum (APH) dengan total kerugian negara mencapai Rp. 1,02 Triliun.

Salah satu penyebab terjadinya kebocoran keuangan Negara yaitu terdapat pada proses pelaksaan Pengadaan Barang dan Jasa yang tidak kompetitif. (Ohashi, 2009) berpendapat bahwa pengaruh dari peningkatan kompetisi pada sisi penawaran adalah memangkas 
kelompok kolusi supaya dapat menurunkan harga. Apabila tidak, kolusi akan hancur karena ada penyimpang (deviator) yang menurunkan penawaran untuk memperoleh keuntungan jangka pendek. Pelaksanaan pengadaan barang/ jasa yang tidak kompetitif akan berdampak pada berkurangnya minat penyedia untuk mengikuti tender dan juga akan menjadi kesempatan bagi pejabat atau pegawai pemerintah untuk melakukan kecurangan atau kolusi dengan perusahaan yang ikut serta dalam tender. Sebuah ilustrasi yang bagus untuk masalah ini yaitu dengan melakukan pengembangan lelang yang kompetitif di seluruh dunia (Amaral, Saussier, \& Yvrande-Billon, 2013). Sudah banyak negara yang telah mengembangkan, menerapkan serta melaksanakan prosedur dan praktik pengadaan publik yang dapat meningkatkan kompetisi, salah satunya termasuk Negara Indonesia.

Kurangnya penelitian tentang pengadaan publik, khususnya di Indonesia, mengakibatkan adanya peluang untuk penilitian yang mendorong penulis melakukan penelitian dalam bidang ini. Data yang akan digunakan untuk penelitian ini diperoleh melalui fasilitas e-tendering pada Layanan Pengadaan Secara Elektronik (LPSE) di Kota Tanjungpinang. Penelitian ini berusaha menelaah pengaruh kompetisi dalam e-procurement terhadap nilai penawaran pemenang atas belanja pemerintah. Dengan menelaah pengaruh tersebut penelitian ini berusaha untuk mengungkapkan factor-faktor yang akan digunakan untuk memastikan usaha dalam memajukan kompetisi didalam Pengadaan Barang/ Jasa dan juga dapat meminimalisirkan alokasi belanja pemerintah. PPK (Pejabat Pembuat Komitmen) dan ULP (Unit Layanan Pengadaan) yang bertugas bagi kepentingan organisasi, 5 mempunyai tujuan untuk mencapai sasaran organisasi serta memiliki prinsip-prinsip untuk menghindar dari resiko merupakan pelaku pengadaan barang/ jasa yang mengupayakan pengadaan berjalan dengan kompetitif melalui pertimbangan pengaruh faktor-faktor kompetisi tender terhadap nilai penawaran pemenang yang nantinya menjadi belanja pemerintah.

Faktor kompetisi yang dapat menjadi bahan pertimbangan ULP dan PPK adalah jumlah peserta untuk menghindari resiko kurangnya peserta dan apabila peserta kurang dari persyaratan yang telah ditentukan maka tender menjadi gagal dan harus dilakukan tender ulang, jarak peserta yang dapat menyebabkan pada nilai penawaran yang terlalu tinggi mengingat biaya transportasi dan biaya pendukung lainnya, nilai pekerjaan yang akan ditenderkan harus sesuai dengan harga pasar yang berbeda pada tiap tahunnya agar para peserta dapat menurunkan harga penawarannya dan lama waktu pekerjaan 
yang dapat mempengaruhi jumlah biaya yang harus dikeluarkan karena semakin lama waktu yang dibutuhkan maka pengeluaran tambahan akan semakin besar. Semua faktor dari kompetisi dapat menyebabkan kenaikan ataupun penurunan pada harga final pada proses pengadaan barang/ jasa. Dengan latar belakang yang seperti ini, penulis ingin mengembangkan penelitian yang menggunakan model pengadaan kompetitif (competitive bidding) yang sebelumnya telah dikembangkan oleh peneliti terdahulu. Model ini melihat pengadaan dalam $e$ procurement dari empat sisi yang berbeda melainkan dari banyaknya jumlah peserta, project size (nilai pekerjaan), dan lama waktu pekerjaan. Selanjutnya faktor-faktor kompetisi ini akan diuji untuk membuktikan pengaruhnya terhadap nilai penawaran pemenang. Dan nilai penawaran pemenang akan dicatat atas nilai belanja pemerintah. Dengan meninjau akan adanya pengaruh kompetisi terhadap besarnya nilai penawaran pemenang serta terjadinya peluang untuk mencapai efisiensi atas belanja pemerintah, maka penulis akan melakukan penelitian dengan judul "Pengaruh Kompetisi dalam $e$ procurement terhadap Nilai Penawaran Pemenang atas Belanja Pemerintah (Studi Empiris Pada Layanan Pengadaan Secara Elektronik Kota Tanjungpinang)”.

\section{Rumusan Masalah :}

1. Apakah jumlah peserta tender dalam e-
Procurement mempengaruhi nilai penawran pemenang atas belanja pemerintah pada (LPSE) Kota Tanjungpinang?

2. Apakah nilai pekerjaan tender pada pekerjaan kontruksi dalam $e$ Procurement mempengaruhi nilai penawaran pemenang atas belanja pemerintah pada layanan pengaaan secara elektronik (LPSE) Kota Tanjungpinang?

3. Apakah lama waktu pekerjaan tender pada pekerjaan konruksi dalam $e$ Procurement mempengaruhi nilai penawaran pemenang atas belanja pemerintah pada LPSE Kota Tanjungpinang?

4. Apakah jumlah peserta tender, jarak peserta tender, nilai pekerjaan tender, serta lama waktu pekerjaan tender secara simultan berpengaruh terhadap nilai penawaran pemenang pada LPSE Kota Tanjungpinang?

\section{Batasan Masalah :}

1. Penelitian dilakukan dengan data tender pada tahun anggaran APBD 2017 dan hanya mengambil tender dalam kategori pekerjaan konturksi dengan total tender sebanyak 34 tender.

2. Menggunakan metode pengadaan yaitu e-Lelang Pemilihan Langsung.

3. Menggunakan metode kualifikasi yaitu Pasca kualifikasi. 


\section{Tujuan Penelitian :}

1. Untuk menganalisis pengaruh jumlah peserta yang ikut serta dalam tender terhadap nilai penawaran pemenang tender pada LPSE Kota Tanjungpinang.

2. Untuk menganalisis pengaruh jarak peserta yang ikut serta dalam tender terhadap nilai penawaran pemenang tender pada LPSE Kota Tanjungpinang.

3. Untuk menganalisis pengaruh nilai pekerjaan yang ditenderkan terhadap nilai penawaran pemenang tender pada layanan pengadaan secara elektronik (LPSE) Kota Tanjungpinang.

4. Untuk menganalisis pengaruh lamanya waktu pekerjaan yang ditenderkan terhadap nilai penawaran pemenang tender pada layanan pengadaan secara elektronik (LPSE) Kota Tanjungpinang.

5. Untuk menganalisis pengaruh jumlah peserta tender, jarak peserta tender, nilai pekerjaan yang ditenderkan, dan lama waktu pengerjaan yang ditenderkan, terhadap nilai penawaran pemenang pada layanan pengadaan 7 secara elektronik (LPSE) Kota Tanjungpinang.

\section{TINJAUAN PUSTAKA}

Pengadaan barang dan jasa merupakan suatu kegiatan untuk memperoleh barang, jasa maupun pekerjaan yang diselenggarakan serta sudah dianggarkan biayanya oleh institusi atau instansi pemerintah, yang pelaksanaannya berdasarkan pada peraturan perundangan yang saat ini berlaku di Indonesia. Selain itu, pengadaan barang dan jasa dapat menjadikan badan/ perorangan yang mempunyai perusahaan untuk ikut andil dalam praktik pengadaan barang dan jasa dengan transparan, kompetitif dan juga dapat meningkatkan efisiensi anggaran dari pemerintah serta dapat mempertahankan kelangsungan hidup perusahaan (Peraturan Presiden Republik Indonesia No. 16 Tentang Pengadaan Barang / Jasa Pemerintah, 2018).

Menurut (Peraturan Presiden Republik Indonesia No.16 Tentang Pengadaan Barang / Jasa Pemerintah, 2018) sebagaimana diubah terakhir dengan Peraturan Presiden No. 54 Tahun 2010 Tentang Pengadaan Barang/ Jasa Pemerintah disebutkan bahwa Pengadaan Barang/ Jasa Pemerintah yang selanjutnya disebut Pengadaan Barang/ Jasa oleh Kementrian/ Lembaga/ Perangkat daerah yang dibiayai oleh APBN (Anggaran Pendapatan dan Belanja Negara)/ APBD (Anggaran Pendapatan dan Belanja Daerah) yang prosesnya sejak identifikasi kebutuhan, sampai dengan serah terima hasil pekerjaan. Pengadaan barang/ jasa dapat dilakukan secara terintegrasi dan dilaksanakan dengan cara swakelola yaitu kegiatan pengadaan barang/ jasa dimana pekerjaannya telah direncanakan, dikerjakan dan/ atau diawasi sendiri oleh Kementrian/ Lembaga/ Perangkat Daerah sebagai penanggung jawab anggaran, instansi pemerintah lain dan/ atau 
kelompok dari masyarakat. Selain itu dapat dengan cara penyedia, yaitu suatu kegiatan untuk memilih atau memfilter badan usaha atau perorangan yang menyediakan barang, pekerjaan kontruksi, jasa konsultasi dan jasa lainnya.

\section{E-procurement}

Lembaga Kebijakan Pengadaan Barang/ Jasa Pemerintah yang disingkat dengan LKPP merupakan lembaga pemerintah nonkementrian yang berada dibawah naungan dan bertanggung jawab kepada Presiden yang memiliki tugas penting yaitu untuk mengembangkan dan merumuskan kebijakan/ peraturan pengadaan barang dan jasa pemerintah sebagaimana dimaksud dalam Peraturan Presiden Nomor 106 Tahun 2007 tentang Lembaga Kebijakan Pengadaan Barang/ Jasa Pemerintah.

Pemerintah Indonesia melahirkan INAPROC (Portal Pengadaan Nasional atau pintu gerbang sistem informasi elektronik yang terkait dengan informasi pengadaan barang/ jasa secara nasional yang dibangun dan dikelola oleh Lembaga Kebijakan Pengadaan Barang/ Jasa Pemerintah Republik Indonesia) pada tahun 2008. Komponen utama Peraturan Presiden Nomor 16 Tahun 2018 mengindikasikan peningkatan transparansi dan kompetisi pengadaan melalui penggunaan teknologi informasi dalam proses pelaksanaan pengadaan barang/ jasa.peraturan tersebut mengklarifikasikan proses pengadaan barang/ jasa secara elektronik dalam format $e$-tendering dan $e$ purchasing yang disebut sebagai $e$ procurement.

Penyelenggaraan Pengadaan Barang/ Jasa dilakukan secara elektornik/ e-procurement menggunakan Sistem Pengadaan Secara Elektronik (SPSE) dan sistem pendukung. Sistem pendukung SPSE meliputi Portal Pengadaan Nasional; Pengelolaan Sumber Daya Manusia Pengadaan Barang/ Jasa; Pengelolaan advokasi dan penyelesaian permasalahan hukum; Pengelolaan peran serta masyarakat; Pengelolaan sumber daya pembelajaran; serta Monitoring dan Evaluasi.

Layanan Pengadaan Secara Elektronik (LPSE) ialah unit kerja Kementrian/ Lembaga/ Perangkat Daerah yang diciptakan untuk menyelenggarakan sistem pelayanan Pengadaan Barang/ Jasa secara elektronik, serta mempunyai fungsi sebagai pengelolaan seluruh sistem informasi Pengadaan Barang/ Jasa dan infrastrukturnya; sebagai pelaksanaan registrasi dan verifikasi pengguna seluruh sistem informasi Pengadaan Barang/ Jasa; dan sebagai pengembangan sistem informasi yang dibutuhkan oleh pemangku kepentingan. Tahun 2018 sudah ada sebanyak 687 LPSE tersebar diseluruh Indonesia. Aplikasi eprocurement ini diharapkan dapat mewujudkan transaparansi, menciptakan efisiensi pengadaan yang lebih baik dalam hal harga yang lebih rendah, biaya kontruksi yang 
lebih murah, dan menjaga standarisasi proses pengadaan agar menjadi lebih baik.

\section{Belanja Pemerintah}

Belanja pemerintah atau disebut pengeluaran pemerintah merupakan salah satu bagian pelaksanaan sumber daya ekonomi yang secara langsung dibawah naungan pemerintah dan secara tidak langsung dimiliki oleh masyarakat melalui pembayaran kewajiban seperti pajak. Pajak merupakan salah satu sumber penerimaan negara yang memiliki peran penting dalam menopang pembiayaan pembangunan dan menggambarkan kemandirian ekonomi. Pada Anggaran Pendapatan dan Belanja Negara (APBN) diketahui pajak merupakan salah satu komponen Penerimaan Negara (Simanjuntak dan Mukhlis, 2012). Pada dasarnya, belanja pemerintah akan meningkatkan sejalan dengan kemajuan kegiatan perekonomian suatu Negara.

Situasi ini dapat dipahami dalam kaidah yang dikenal sebagai Hukum Wagner, yaitu mengenai adanya korelasi positif antara belanja pemerintah dengan tingkat pendapatan nasional. Meskipun demikian, peningkatan belanja daerah yang besar belum tentu berdampak baik terrhadap aktivitas perekonomian. Menurut (Peraturan Menteri Keuangan Nomor 101/PMK.02/2011 tentang klasifikasi anggaran) Belanja modal merupakan salah satu jenis belanja pemerintah yang pengeluran atau belanjanya untuk pembayaran perolehan asset dan/ atau menambah nilai asset tetap/ asset lainnya yang memberi manfaataat lebih dari satu periode akuntansi dan melebihi batas minimal kapitalisasi asset tetap/ asset lainnya yang ditatapkan pemerintah.

Pemerintah dituntut harus mengoptimalkan pengalokasian dari anggarannya dengan menggunakan dana serta daya seminimal mungkin untuk memperoleh barang/ jasa yang nantinya dapat meningkatkan pada layanan publik. Anggaran belanja pemerintah terbatas, untuk itu efisiensi menjadi sangat penting guna mencapai tujuan pemerintah. Problema efisiensi belanja pemerintah tersebut yang akan menjadi titik utama dalam penelitian ini. Dan pada kompetisi dalam e-procurement, nilai penawaran pemenang yang diperoleh, diharapkan merupakan nilai kompetitif untuk memperoleh apa yang diinginkan secara seefisien. Variabel Nilai penawaran pemenang merupakan nilai yang harus dibayarkan atau yang wajib dikeluarkan oleh pemerintah kepada peserta tender yang telah dinyatakan sebagai pemenang tender untuk melaksanakan proses pekerjaan tender. Variabel ini merupakan variabel dependen/ variabel terikat dalam penelitian ini. Indikator yang digunakan dalam variabel ini dibentuk dari rasio nilai penawaran pemenang terhadap Harga Perkiraan Sendiri (HPS) dengan cara membagi jumlah nilai penawaran pemenang dengan Harga Perkiraan Sendiri (HPS). 


\section{Kompetisi Pengadaan Barang/ Jasa}

Kompetisi Pengadaan Barang/ Jasa merupakan sebuah kompetisi atau persaingan yang terjadi didalam suatu tender pengadaan barang/ jasa yang diikuti oleh beberapa peserta tender (bidder). Pada tender pengadaan barang/ jasa, harga penawaran yang rendah serta mampu melengkapi seluruh persyaratan dan memebuhi kebutuhan tender dari antara semua penawaran yang masuk akan dinyatakan sebagai pemenang tender. Nilai penawaran pemenang tender yang diperoleh selanjutnya yang akan menjadi nilai belanja pemerintah. (Grega dan Nemec 2015) mengungkapkan bahwa persaingan atau kompetisi memiliki dampak yang bagus pada harga akhir, tetapi juga jika syarat telah memenuhi kriteria dari harga terendah dan pembiayaan melalui Negara juga mempengaruhi harga akhir pada pengadaan. Kompetisi dalam suatu tender pengadaan barang/ jasa dapat dipahami dari beberapa sisi. Dan didalam penelitian ini, persaingan/ kompetisi pengadaan barang/ jasa akan diteliti dari lima sisi yang berbeda. Kompetisi/ persaingan akan diteliti berdasarkan junlah peserta tender, jarak peserta tender, nilai pekerjaan yang ditenderkan, lama waktu pekerjaan tender dan kemenangan masa lalu yang pernah diraih oleh peserta tender.

\section{Jumlah Peserta Tender}

Menurut (Hanák \& Muchová, 2015) Jumlah peserta tender yang menagjukan penawaran mempengaruhi rasio antara harga yang diekpektasikan dan nilai pemenangan lelang. Sebuah persaingan atau biasa disebut kompetisi dapat dilihat dari sisi banyaknya jumlah peserta yang ikut serta dalam suatu tender pengadaan barang/ jasa. Banyaknya jumlah pesaing (competitor) adalah ukuran penting yang memperlihatkan eksitensi dan intensitas kompetisi dalam suatu kegiatan tender pengadaan barang/ jasa ini. Semakin banyak peserta yang ikut serta maka semakin kompetitif proses pengadaan barang/ jasa tersebut.

\section{Nilai Pekerjaan Tender}

Kompetisi tender pengadaan barang/ jasa melibatkan masing-masing proyek dengan nilai yang berbeda. Menurut (Rudi \& Haryanto, 2013) bahwa nilai pekerjaan yang ditenderkan berpengaruh negatif terhadap biaya kontruksi yang dicatat sebagai nilai penawaran pemenang. Artinya semaki besar nilai pekerjaan, maka biaya tambahan yang dikeluarkan oleh pemerintah akan semakin rendah

Perbedaan nilai pekerjaan tender pada kompetis ini memungkinkan akan berpengaruh terhadap hasil akhir pada tender dalam bentuk presentase keuntungan yang ditanggungkan penyedia pada nilai penawaran pemenang. Para peserta tender akan cenderung mengambil presentase 
keuntungan yang lebih rendah karena nilai nominalnya akan lebih besar sedangkan dalam hal kompetisi tender yang nilainya kecil, para peserta akan cenderung mengharapkan presentase keuntungan yang lebih besar. Contohnya peserta mungkin lebih meyukai mendapatkan presentase keuntungan $8 \%$ dari nilai pengadaan barang/ jasa satu miliyar (1M) daripada $10 \%$ dari seratus juta (100 JT).

Variabel nilai pekerjaan yang ada pada pengadaan barang/ jasa memperlihatkan nilai proyek pekerjaan kontruksi yang ditenderkan. Variabel ini memiliki deskripsi perbedaan mengenai ukuran pekerjaan kontruksi pada masing-masing lelang. Indikator yang digunakan untuk mengukur variabel dalam penelitian ini adalah Nilai Harga Perkiraan Sendiri (HPS), dimana Harga Perkiraan Sendiri itu merupakan perkiraan nilai pekerja kontruksi yang dibuat oleh pejabat pengadaan/ unit layanan pengadaan (ULP).

\section{Lama Waktu Pekerjaan Tender}

Peserta tender yang nantinya akan menjadi penyedia, mendapatkan kewajiban untuk meyelesaikan pekerjaan yang sudah dimenangkan dalam jangka waktu yang sudah ditetapkan, juga akan mengupayakan sumber daya yang tepat serta ahli/ terampil pada pengerjaan proyek tersebut.

Menurut (Li, Kahn, \& Nickelsburg, 2015) menyatakan bahwa pada sektor publik, waktu untuk menyelesaikan suatu tender secara signifikan mempengaruhi kesejahteraan dan kondisi sosial konsumer. Lamanya waktu pengerjaan proyek sering kali menjadi suatu syarat yang sangat penting bagi pelaksanaan proyek dari instansi pemerintah, karena penyedia akan mempertimbangkan secara rinci berapa jumlah sumber daya yang harus dikeluarkan dan berapa jumlah presentase keuntungan yang ditanggungkan dalam penawaran yang nantinya berpengaruh pada harga penawaran pemenang peserta tender. Dan apabila lama waktu pengerjaan semakin lama, maka semakin besar belanja pemerintah yang harus dikeluarkan.

\section{Hipotesis Penelitian}

H1 : Jumlah peserta tender berpengaruh terhadap nilai penawaran pemenang atas belanja pemerintah.

H2 : Nilai Pekerjaan yang ditenderkan berpengaruh terhadap nilai penawaran pemenang atas belanja pemerintah.

H3 : Lama waktu Pekerjaan Kontruksi berpengaruh terhadap nilai penawaran pemenang atas belanja pemerintah.

H4 : Jumlah, Nilai Pekerjaan, Lama Waktu Pekerjaan, dan Kemenangan Masa Lalu yang ditenderkan berpengaruh simultan terhadap Nilai Penawaran Pemenang atas Belanja Pemerintah.

\section{METODOLOGI PENELITIAN}




\section{Jenis Penelitian}

Jenis penelitian ini menggunakan metode penelitian kuantitatif. Penelitian kuantitatif merupakan data yang bersifat angka-angka yang berasal dari perhitungan masing-masing atribut dalam pengukuran variabel. Peneltian kuantitatif dinamakan penelitian ilmiah karena sudah memenuhi pedoman-pedoman ilmiah yaitu konkrit, objektif, terarah, logis dan terstruktur. (Sugiyono, 2014).

Dalam melakukan analisis data dalam penelitian ini menggunakan program JASP (Jeffreys's Amazing Statistics Program.) versi 0.14.10.

\section{Jenis Data}

Data sekunder merupakan data yang berasal dari bagian atau institusi yang telah menyediakan, memanfaatkan atau mempublikasikannya. Data sekunder sudah dapat dipastikan pemanfaatannya dan dipublikasi, maka tidak diperlukan lagi untuk menguji keabsahan kebenaran dan keterjaminannya (Chandrarin, 2017).

\section{Metode Pengumpulan Data}

1. Wawancara Menurut (Sugiyono, 2012) wawancara ialah pertemuan dua orang untuk saling berbagi informasi melalui tanya jawab sehingga dapat diketahui makna dalam suatu topik tertentu dan dengan wawancara, peneliti dapat mengetahui hal yang lebih mendalam dalam menginterprestasikan situasi dan fenomena yang terjadi yang tidak mungkin bisa ditemukan melalui observasi. Wawancara dalam penelitian ini dilakukan pada pejabat/ pegawai di LPSE Kota Tanjungpinang.

2. Observasi Menurut (Sunyoto, 2011) metode observasi adalah metode pengumpulan data dengan melakukan pengamatan secara langsung atau observasi kelapangan yang berhubungan dengan objek penelitian. Observasi yang dimaksud didalam penelitian ini adalah berupa kegiatan-kegiatan penagamatan secara langsung terhadap Nilai Penawaran Pemenang atas Belanja Pemerintah melalui Kantor Layanan Pengadaan Secara Elektronik (LPSE) Kota Tanjungpinang.

3. Studi Pustaka Menurut (Arikunto, 2010) Studi Pustaka adalah metode pengumpulan data dengan cara mencari informasi melalui buku, koran, majalah dan literature lainnya. Studi pustaka yang dimaksud adalah mempelajari dan mengutip teori-teori yang berkaitan dengan judul penelitian ini.

\section{Populasi Dan Sampel}

Populasi merupakan kawasan atau wilayah generalisasi yang terdiri atas: objek/ subjek yang memiliki kualitas dan sifat/ karakteristik yang telah ditetapkan oleh peneliti untuk dipahami serta dipelajari dan kemudian dapat ditemukan kesimpulannya. Populasi bukan 
hanya sekedar jumlah yang ada pada objek/ subjek yang dipahami serta dipelajari, melainkan meliputi seluruh sifat/ karakteristik yang dimilki oleh objek atau subjek itu sendiri. (Sugiyono, 2014). Populasi dari penelitian ini adalah pekerjaan kontruksi yang ditenderkan melalui fasilitas elektronik LPSE Kota Tanjungpinang dengan mengakses Laman SPSE Versi 4.3 pada tahun anggaran 2017. Pemilihan sampel dilakukan dengan secara sampel jenuh (saturation sampling) yaitu mengambil seluruh populasi sebagai sampel yang akan diteliti. Hal ini dikarenakan jumlah populasi pekerjan kontruksi yang ditenderkan pada eprocurement LPSE Kota Tanjungpinang tahun 2017 berjumlah sedikit yaitu 34 tender pekejaan kontruksi.

\section{Definisi Operasional Variabel}

1. Nilai Penawaran Pemenang (Dependen): Rasio nilai penawaran pemenang tender terhadap HPS (dalam persen).

2. Jumlah Peserta Tender (Independen): Jumlah peserta yang mengikuti tender.

3. Nilai Pekerjaan Tender (Independen): Nilai Harga Perkiraan Sendiri/ HPS (dalam ratusan juta).

4. Lama Waktu Pekerjaan Tender (Independen): Syarat lama waktu pekerjaan dalam kontrak (dalam hari).

\section{HASIL DAN PEMBAHASAN}

\section{Gambaran Umum Objek Penelitian}

Layanan Pengadaan Secara Elektornik (LPSE) adalah layanan pengelolaan teknologi informasi untuk memfasilitasi pelaksanaan Pengadaan Barang/ Jasa secara Elektornik. Pengadaan barang/ jasa elektronik akan meningkatkan transparansi dan akuntabilitas, meningkatkan akses pasar dan persaingan usaha yang sehat, memperbaiki tingkat efisiensi proses pengadaan, mendukung proses monitoring dan audit dan memenuhi kebutuhan akses informasi yang real time untuk menciptakan clean and good government dalam pengadaan barang/ jasa pemerintah.

Tabel 1. Data Penelitian Pekerjaan Kontruksi Tahun Anggaran 2017

\begin{tabular}{|c|c|c|c|c|}
\hline $\begin{array}{l}\mathrm{N} \\
\mathrm{o}\end{array}$ & $\begin{array}{l}\text { Jumlah } \\
\text { Peserta } \\
\text { Tender }\end{array}$ & $\begin{array}{l}\text { Nilai } \\
\text { Pekerja } \\
\text { an } \\
\text { Tender }\end{array}$ & $\begin{array}{l}\text { Lama } \\
\text { Waktu } \\
\text { Pekerja } \\
\text { an }\end{array}$ & $\begin{array}{l}\text { Nilai } \\
\text { Penawa } \\
\text { ran } \\
\text { Pemena } \\
\text { ng }\end{array}$ \\
\hline & 22 & 1317 & 180 & 93 \\
\hline & 39 & 1200 & 180 & 87.88 \\
\hline & 35 & 289 & 150 & 99 \\
\hline & 25 & 425 & 120 & 89.86 \\
\hline & 30 & 259 & 90 & 99 \\
\hline & 33 & 425 & 90 & 97 \\
\hline & 32 & 410 & 90 & 96.59 \\
\hline & 21 & 3499 & 210 & 90 \\
\hline & 20 & 312 & 90 & 96 \\
\hline & 32 & 350 & 120 & 99 \\
\hline & 34 & 370 & 90 & 97 \\
\hline & 33 & 650 & 120 & 99 \\
\hline & 18 & 650 & 120 & 97 \\
\hline & 25 & 1500 & 210 & 99.4 \\
\hline & 33 & 3800 & 210 & 92.3 \\
\hline & 23 & 1500 & 90 & 78.25 \\
\hline & 23 & 2472 & 120 & 83.33 \\
\hline & 19 & 4000 & 210 & 95.3 \\
\hline & 25 & 4200 & 210 & 96.91 \\
\hline & 21 & 3173 & 180 & 92 \\
\hline & 23 & 700 & 180 & 99 \\
\hline
\end{tabular}




\begin{tabular}{|c|c|c|c|}
\hline 42 & 1795 & 120 & 86.96 \\
\hline 50 & 1700 & 180 & 90 \\
\hline 55 & 2600 & 180 & 90 \\
\hline 26 & 1291 & 150 & 94.66 \\
\hline 24 & 1200 & 120 & 95.08 \\
\hline 27 & 751 & 90 & 95 \\
\hline 49 & 950 & 180 & 89.78 \\
\hline 53 & 2500 & 120 & 87.72 \\
\hline 50 & 2945 & 180 & 87.02 \\
\hline 38 & 3440 & 150 & 86.6 \\
\hline 32 & 1298 & 210 & 95.45 \\
\hline 27 & 908 & 180 & 96.59 \\
\hline 57 & 1600 & 180 & 90 \\
\hline
\end{tabular}

Sumber: Data Penelitian diolah

\section{Jumlah Peserta Tender (X1)}

Jumlah peserta yang mengikuti tender pekerjaan kontruksi tahun anggaran 2017 pada masing-masing tender yang berjumlah 34 paket tender serta mengalami fluktuasi yang signifikan. Signifikannya jumlah peserta yang ikut dalam proses pengadaan ini disebabkan oleh tingginya jumlah kompetitor yang berlomba-lomba mengajukan penawaran serendah mungkin agar masuk dalam kriteria penawaran yang telah ditetapkan oleh pemerintah dan semakin banyak yang ikut proses pengadaan $e$ procurement maka akan semakin agresif persaingan para kompetitor untuk mempertahankan nilai penawaran mereka agar dapat memenangkan tender tersebut. Jika dilihat kemampuan peserta tender dalam mengikuti proses pengadaan, peserta yang mengikuti paling banyak berjumlah 57 peserta tender dan peserta yang paling sedikit berjumlah 18 peserta. Jika dilihat dari grafik, jumlah peserta tender yang mengikuti proses pengadaan e-procurement menunjukkan bahwa tingkat persaingan dalam tender pengadaan pekerjaan kontruksi tergolong kompetitif.

\section{Nilai Pekerjaan Tender (X2)}

Nilai Pekerjaan Tender dari Harga Perkiraan Sendiri (HPS) yang ditenderkan pada fasilitas $e$-tendering layanan pengadaan secara elektronik (LPSE) Kota Tanjungpinang pada masing-masing paket tender anggaran tahun 2017 mengalami fluktuasi yang signifikan. Nilai Pekerjaan Tender dari Harga Perkiraan Sendiri (HPS) memiliki nilai terendah sebesar 259 dalam (ratusan juta) atau sebesar Rp. 259.000.000, angka tersebut sesuai dengan batasan ketentuan Nilai Pekerjaan Kontruksi yang harus ditenderkan melalui pelelangan umum dengan nilai diatas Rp 200.000.000. Pada penelitian ini, tidak terdapat nilai pekerjaan tender dibawah ketentuan Nilai Pekerjaan Kontruksi yang dtenderkan melalui pelelangan umum dengan nilai $\mathrm{Rp}$. 200.000.000. Dan nilai pekerjaan tender yang tertinggi dari masing-masing paket tender sebesar 4200 dalam (ratusan juta) atau sebesar Rp. 4.200.000.000.

\section{Lama Waktu Pekerjaan Tender (X3)}

Lama Waktu Pekerjaan Tender menunjukkan perbedaan pada masing-masing paket. Lama waktu pekerjaan tender dengan kurun waktu sedikitnya 90 hari dan dengan 
kurun waktu terbanyak yaitu 210 hari. Lama waktu pengerjaan tender ini sudah termasuk dengan proses tender untuk mendapatkan pemenang dan hasil akhir dari pekerjaan kontruksi yang didapat. Dalam hal ini, lama waktu juga sangat menentukan kemampuan dan kesanggupan untuk menyelesaikan lama waktu yang dibuat agar tidak adanya penambahan pada biaya lain-lain khususnya pada belanja pemerintah.

\section{Nilai Penawaran Pemenang $(Y)$}

Nilai Penawaran Pemenang Tender Pekerjaan Kontruksi Tahun anggaran 2017 pada masing-masing paket tender terlihat fluktuasi. Nilai Penawaran Pemenang Tender merupakan biaya yang harus dikeluarkan pemerintah, dan hasil dari grafik merupakan pengukuran dari nilai penawaran yang diajukan oleh peserta tender dengan membagi Harga Perkiraan Sendiri (HPS). Persentase Nilai Penawaran Pemenang tertinggi sebesar 99.40\% dimana Nilai Penawaran Rp. 1.491.500.000 dan HPS Rp. 1.500.000.000, sementara itu presentase terendah sebesar $78.25 \%$ dimana Nilai Penawaran Nilai Penawaran Pemenang Tender Pekerjaan Kontruksi Tahun anggaran 2017 pada masing-masing paket tender terlihat fluktuasi. Nilai Penawaran Pemenang Tender merupakan biaya yang harus dikeluarkan pemerintah, dan hasil dari grafik merupakan pengukuran dari nilai penawaran yang diajukan oleh peserta tender dengan membagi
Harga Perkiraan Sendiri (HPS). Persentase Nilai Penawaran Pemenang tertinggi sebesar 99.40\% dimana Nilai Penawaran Rp. 1.491.500.000 dan HPS Rp. 1.500.000.000, sementara itu presentase terendah sebesar $78.25 \%$ dimana Nilai Penawaran Rp. 1.173.792.000 dan HPS Rp. 1.500.00.000.

\section{Analisis Data}

\section{Uji Asumsi Klasik}

a. Uji Normalitas

\section{Gambar 1 \\ Hasil Uji Normalitas}

Q-Q Plot Standardized Residuals

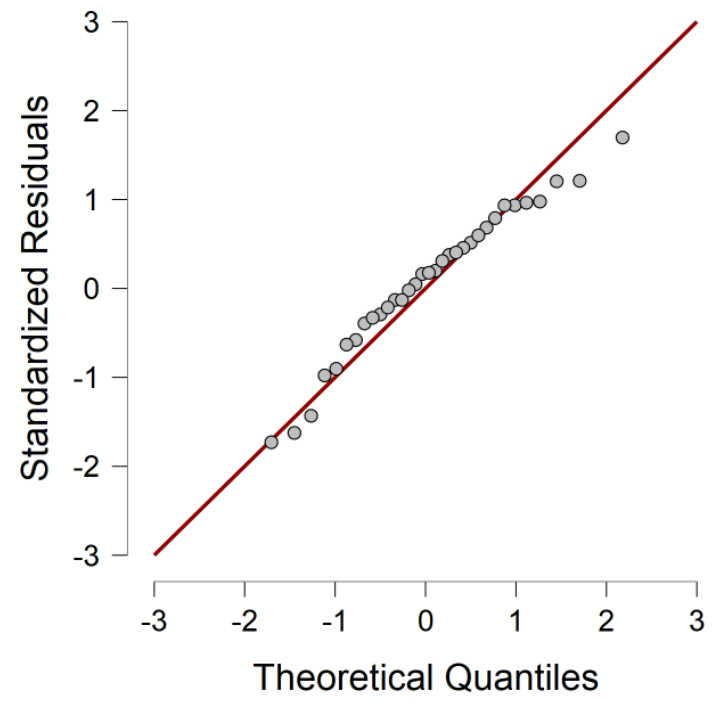

Standardized Residuals Histogram

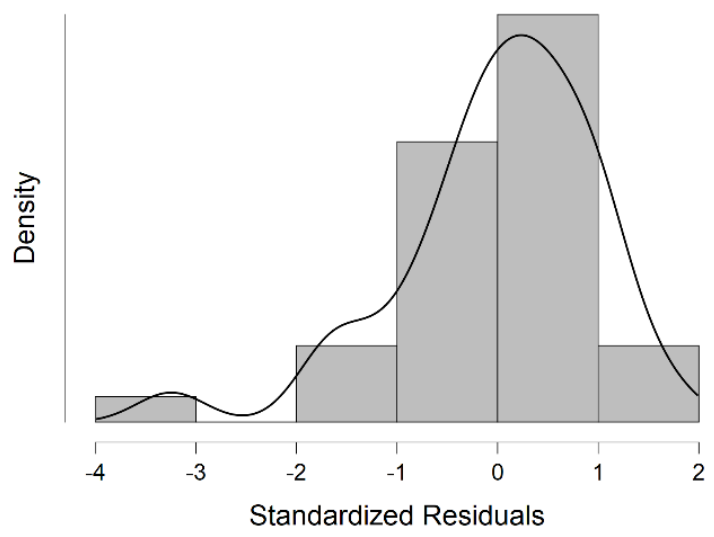

Sumber: Data Penelitian Diolah

Berdasarkan tabel pengujian 
normalitas Q-Q Plot, Grafik

Histogram diatas menunjukkan data berdistribusi secara normal, hal ini dilihat dari titik-titik plot berada atau mengukuti garis diagonal.

b. Uji Multikolinieritas

Untuk menguji multikolinieritas dengan cara melihat nilai VIF masing-masing variabel independen, jika nilai VIF $<10$, maka dapat disimpulkan data bebas dari gejala multikolinieritas.

Tabel 2

Hasil Uji Multikolinieritas

\begin{tabular}{lrc}
\hline \multicolumn{3}{c}{ Collinearity Statistics } \\
\hline Variabel & Tolerance & VIF \\
\hline Jumlah Peserta Tender (X1) & 0.989 & 1.011 \\
Nilai Pekerjaan Tender (X2) & 0.627 & 1.595 \\
Lama Waktu Pekerjaan (X3) & 0.623 & 1.604 \\
\hline
\end{tabular}

Sumber: Data Penelitian Diolah

c. Uji Heteroskedastisitas

Dari gambar yang ditambilkan dibawah dapat dilihat bahwa tidak ada pola tertentu karena titik meyebar tidak beraturan di atas dan di bawah sumbu 0 pada sumbu Y, sehingga dapat disimpulkan tidak terdapat gejala heteroskedastisitas.

Gambar 2

Hasil Uji Heteroskedastisitas

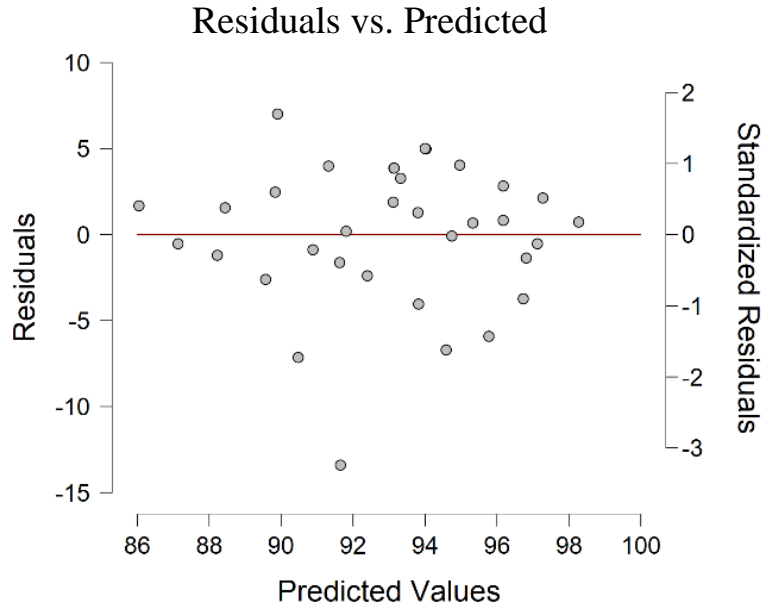

Sumber: Data Penelitian Diolah

d. Uji Autokorelasi

Berdasarkan data tabel diatas, hasil uji autokorelasi menunjukkan tidak adanya autokorelasi $(\mathrm{du}<\mathrm{d}<$ 4-du) dengan nilai hitung Durbin Watson sebesar 1,679 atau berada diantara 1,6419-2,3481.

\section{Persamaan Regresi}

Hasil persamaan regresi dalam penelitian ini dapat dilihat dibawah ini:

Tabel 3

Hasil Persamaan Regresi

Coefficients

\begin{tabular}{|c|c|c|c|c|c|c|}
\hline \multicolumn{2}{|c|}{ Model } & \multirow{2}{*}{$\begin{array}{r}\begin{array}{r}\text { Unstand } \\
\text { ardized }\end{array} \\
92.991\end{array}$} & \multirow{2}{*}{$\begin{array}{r}\begin{array}{c}\text { Stand } \\
\text { rd } \\
\text { Error }\end{array} \\
0\end{array}$} & Standardized & \multirow{2}{*}{$\begin{array}{c}\mathbf{t} \\
105.152\end{array}$} & \multirow{2}{*}{$\begin{array}{l}\mathbf{p} \\
<.001\end{array}$} \\
\hline $\mathrm{H}_{0}$ & $\begin{array}{l}\text { (Inter } \\
\text { cept) }\end{array}$ & & & & & \\
\hline \multirow[t]{4}{*}{$\mathrm{H}_{1}$} & $\begin{array}{l}\text { (Inter } \\
\text { cept) }\end{array}$ & 94.644 & 3.391 & & 27.913 & $<.001$ \\
\hline & (X1) & -0.145 & 0.068 & -0.314 & -2.139 & 0.041 \\
\hline & (X2) & -0.003 & $7.852 \mathrm{e}-4$ & -0.642 & -3.478 & 0.002 \\
\hline & (X3) & 0.049 & 0.022 & 0.418 & 2.256 & 0.032 \\
\hline
\end{tabular}

Sumber: Data Penelitian Diolah

$\mathrm{Y}=94,644-0,145 x_{1}-0,003 x_{2}+$ $0,049 x_{3}+e$ 


\section{Pengujian Hipotesis}

Tabel 4

Uji Parsial (Uji $t$ )

Coefficients

\begin{tabular}{|c|c|c|c|c|c|c|}
\hline \multicolumn{2}{|c|}{ Model } & \multirow{2}{*}{$\begin{array}{r}\begin{array}{r}\text { Unstand } \\
\text { ardized }\end{array} \\
92.991 \\
\end{array}$} & $\begin{array}{l}\text { Standa } \\
\text { rd } S t \\
\text { Error }\end{array}$ & andardized & \multirow{2}{*}{$\begin{array}{c}\mathbf{t} \\
105.152\end{array}$} & \multirow{2}{*}{$\begin{array}{l}\mathbf{p} \\
<.001\end{array}$} \\
\hline $\mathrm{H}_{0}$ & $\begin{array}{l}\text { (Inter } \\
\text { cept) }\end{array}$ & & 0.884 & & & \\
\hline \multirow[t]{4}{*}{$\mathrm{H}_{1}$} & $\begin{array}{l}\text { (Inter } \\
\text { cept) }\end{array}$ & 94.644 & 3.391 & & 27.913 & $<.001$ \\
\hline & (X1) & -0.145 & 0.068 & -0.314 & -2.139 & 0.041 \\
\hline & (X2) & -0.003 & $7.852 \mathrm{e}-4$ & -0.642 & -3.478 & 0.002 \\
\hline & (X3) & 0.049 & 0.022 & 0.418 & 2.256 & 0.032 \\
\hline
\end{tabular}

Sumber: Data Penelitian Diolah

Berdasarkan hasil pengujian uji $t$ diatas, secara parsial jumlah peserta tender berpengaruh negatif terhadap nilai penawaran pemenang atas belanja pemerintah dengan menggunakan program JASP (Jeffreys's Amazing Statistics Program.) versi 0.14.10, diperoleh $t$ hitung sebesar -2,139>t tabel 2.034 dengan sig 0,028. Karena nilai sig $0,041<0,05$ dapat disimpulkan bahwa ada pengaruh yang signifikan antara jumlah peserta tender terhadap nilai penawaran pemenang. Hal ini berarti bahwa hipotesis pertama yang menyatakan bahwa jumlah peserta tender berpengaruh terhadap nilai penawaran pemenang atas belanja pemerintah di Layanan Pengadaan Secara Elektornik (LPSE) Kota Tanjungpinang diterima.

Berdasarkan hasil pengujian uji $t$ diatas, secara parsial nilai pekerjaan tender/ HPS berpengaruh terhadap nilai penawaran pemenang atas belanja pemerintah dengan menggunakan program JASP (Jeffreys's Amazing Statistics Program.) versi 0.14.10, diperoleh $t_{\text {hitung }}$ sebesar $-3,478>t_{\text {tabel }}-$ 2.034 dengan sig $0,002<0,05$ dapat disimpulkan bahwa ada pengaruh yang signifikan antara nilai pekerjaan tender/ HPS terhadap nilai penawaran pemenang. Hal ini berarti bahwa hipotesis ketiga yang menyatakan nilai pekerjaan yang tenderkan berpengaruh negatif terhadap nilai penawaran pemenang atas belanja pemerintah pada Layanan Pengadaan Secara Elektronik (LPSE) Kota Tanjungpinang diterima.

Berdasarkan hasil pengujian uji $t$ diatas, secara parsial lama waktu pekerjaan yang ditenderkan berpengaruh terhadap nilai penawaran pemenang atas belanja pemerintah dengan menggunakan program JASP (Jeffreys's Amazing Statistics Program.) versi 0.14.10, diperoleh $t_{\text {hitung }}$ sebesar 2,256 > $t_{\text {tabel }}$ 2,034 (2,256 lebih besar dari 2,045) dengan sig $0,032<0,05(0,032$ lebih kecil $0,05)$ dapat disimpulkan bahwa ada pengaruh yang signifikan antara lama waktu pekerjaan yang ditenderkan terhadap nilai penawaran pemenang. Hal ini berarti bahwa hipotesis keempat yang menyatakan lama waktu pekerjaan kontruksi berpengaruh positif terhadap nilai penawaran pemenang atas belanja pemerintah pada Layanan Pengadaan Secara Elektronik (LPSE) Kota Tanjungpinang diterima.

Tabel 5

\section{Uji Simultan (Uji F)}

\begin{tabular}{|c|c|c|c|c|c|c|}
\hline \multicolumn{7}{|c|}{ ANOVA } \\
\hline Model & & $\begin{array}{l}\text { Sum of } \\
\text { Squares }\end{array}$ & df & $\begin{array}{c}\text { Mean } \\
\text { Square }\end{array}$ & $\mathbf{F}$ & $\mathbf{p}$ \\
\hline \multirow[t]{2}{*}{$\overline{\mathrm{H}_{1}}$} & Regression & 314.645 & 3 & 104.882 & 5.590 & 0.004 \\
\hline & Residual & 562.835 & 30 & 18.761 & & \\
\hline
\end{tabular}


ANOVA

\begin{tabular}{|c|c|c|c|c|c|}
\hline Model & $\begin{array}{c}\text { Sum of } \\
\text { Squares }\end{array}$ & df & $\begin{array}{c}\text { Mean } \\
\text { Square }\end{array}$ & $\mathbf{F}$ & $\mathbf{p}$ \\
\hline Total & 877.480 & 33 & & & \\
\hline
\end{tabular}

Note. The intercept model is omitted, as no meaningful information can be shown.

Sumber: Data Penelitian Diolah

Hasil uji $\mathrm{F}$ diatas menunjukkan bahwa jumlah peserta tender (X1), nilai pekerjaan tender (X2) dan lama waktu pekerjaan (X3) berpengaruh signifikan terhadap nilai penawaran pemenang atas belanja pemerintah pada Layanan Pengadaan Secara Elektronik (LPSE) Kota Tanjungpinang, karena hasil penelitian menunjukkan bahwa nilai signifikansi 0,004 lebih kecil dari 0,05. Dan nilai $\mathrm{F}$ hitung sebesar 5,590 lebih besar dari F tabel sebesar 2,88 sehingga dapat disimpulkan bahwa hipotesis kelima diterima, artinya secara simultan jumlah peserta, nilai pekerjaan dan lama waktu pekerjaan yang ditenderkan berpengaruh terhadap nilai penawaran pemenang atas belanja pemerintah.

\section{Tabel 6}

Uji Koefisien Determinasi $\left(\boldsymbol{R}^{2}\right)$

Model Summary - Nilai Penawaran Pemenang (Y)

\begin{tabular}{|c|c|c|c|c|c|c|c|c|}
\hline Model & $\mathbf{R}$ & $\mathbf{R}^{2}$ & $\begin{array}{c}\text { Adjusted } \\
\mathbf{R}^{\mathbf{2}} \\
\end{array}$ & RMSE & $\begin{array}{c}\mathbf{R}^{2} \\
\text { Change }\end{array}$ & $\begin{array}{c}\text { F } \\
\text { Change }\end{array}$ & df1 df2 & $\mathbf{p}$ \\
\hline $\mathrm{H}_{0}$ & 0.000 & 0.000 & 0.000 & 5.157 & 0.000 & & $\begin{array}{ll}0 & 33\end{array}$ & \\
\hline $\mathrm{H}_{1}$ & 0.599 & 0.359 & 0.294 & 4.331 & 0.359 & 5.590 & 330 & 0.004 \\
\hline
\end{tabular}

Sumber: Data Penelitian Diolah

Nilai R Square diatas menunjukkan 0,359 atau 36\% menunjukkan sekitar 36\% Variabel Y (nilai penawaran pemenang atas belanja pemerintah) dapat dijelaskan oleh variabel jumlah peserta, nilai pekerjaan dan lama waktu yang ditenderkan atau dapat dikatakan bahwa kontribusi jumlah peserta, jarak peserta, nilai pekerjaan dan lama waktu pekerjaan yang ditenderkan terhadap nilai penawaran pemenang atas belanja pemerintah adalah sebesar $36 \%$. Sisanya sebesar $64 \%$ dijelaskan oleh variabel lain yang tidak dimasukkan didalam penelitian ini.

\section{PENUTUP}

\section{Simpulan}

1. Jumlah Peserta Tender berpengaruh negatif dan signifikan terhadap nilai penawaran pemenang atas belanja pemerintah pada Layanan Pengadaan Secara Elektronik (LPSE) Kota Tanjungpinang. Hal ini dapat dilihat dengan nilai sig sebesar $0,041<0,05$ dengan $t$ hitung $-2,139>t$ tabel $-2,034$.

2. Nilai Pekerjaan Tender berpengaruh negatif dan signifikan terhadap nilai penawaran pemenang atas belanja pemerintah pada Layanan Pengadaan Secara Elektronik (LPSE) Kota Tanjungpinang. Hal ini dapat dilihat dengan nilai sig sebesar $0,002<0,05$ dengan $\mathrm{t}_{\text {hitung }}-3,478>\mathrm{t}_{\text {tabel }}-2,034$.

3. Lama Waktu Pekerjaan Tender berpengaruh positif dan signifikan terhadap nilai penawaran pemenang atas belanja pemerintah pada Layanan Pengadaan Secara Elektronik (LPSE) Kota Tanjungpinang. Hal ini dapat dilihat dengan nilai sig sebesar $0,032<$ 0,05 dengan $\mathrm{t}_{\text {hitung }} 2,256>\mathrm{t}_{\text {tabel }} 2,034$.

4. Jumlah peserta, jarak peserta, nilai pekerjaan tender dan lama waktu 
pekerjaan tender secara simultan berpengaruh terhadap nilai penawaran pemenang atas belanja pemerintah pada Layanan Pengadaan Secara Elektronik (LPSE) Kota Tanjungpinang. Hal ini dapat dilihat dengan nilai sig sebesar 0,004 yang lebih kecil dari 0,05 dengan $F_{\text {hitung }} 5,590$ lebih besar dari $F_{\text {tabel }} 2,88$.

\section{Saran}

1. Dalam penelitian ini memberitahukan bahwa jumlah peserta berpengaruh negatif terhadap nilai penawaran pemenang. Karena itu, pihak penyelenggara tender disarankan terus berupaya menarik banyak peserta untuk mengikuti tender dengan contoh memperbanyak tender maupun memberikan syarat kualifikasi perusahaan yang sesuai dengan kebutuhan pengadaan.

2. Dalam penelitian ini menjelaskan bahwa nilai pekerjaan tender berpengaruh negatif terhadap nilai penawaran pemenang. Karena itu, pihak penyelenggara tender disarankan dalam membuat harga perkiraan sendiri dapat masuk dengan harga pasar, sehingga dengan besarnya nilai pekerjaan tender yang ditenderkan maka peserta dapat mengkalkulasikan biaya dengan minim.

3. Dalam penelitian ini lama waktu pekerjaan berpengaruh positif terhadap nilai penawaran pemenang, maka pejabat pembuat komitmen (PPK) selaku yang membuat kerangka acuan kerja (KAK) disarankan untuk semakin teliti dalam menghitung lama waktu pekerjaan dibutuhkan. Apabila lama waktu pekerjaan dapat dipersingkat maka nilai penawaran pemenang atas belanja pemerintah dapat berkurang.

4. Terkait keterbatasan penelitian ini, disarankan peneliti selanjutnya menggunakan metode pengambilan sampel berbeda yaitu random sampling untuk mengetahui perbedaan yang akan diketahui jika dibandingkan dengan hasil penelitian ini. Selain itu, peneliti selanjutnya dapat menambahkan variabel lain yang mungkin dapat meningkatkan tingkat pengaruh yang dihasilkan penelitian ini, misalnya variabel kemenangan sebelumnya yaitu pengalaman peserta tender dalam memenangkan tender.

\section{DAFTAR PUSTAKA}

Athias, L., \& Nunez, A. (2008). The More the Merrier? Number of Bidders, Information Dispersion, Renegotiation and Winner's Curse in Toll Road Concessions. SSRN. https://doi.org/10.2139/ssrn.1269630

Arikunto, S. (2010). Suatu Pendekatan Praktik. Cetakan Ke-14. Jakarta. https://doi.org/10.1371/journal.pone.0 035079

Chandrarin, grahita. (2017). Metode Riset Akuntansi Pendekatan Kuantitatif. Jakarta: salemba empat. Jakarta. 
Danang, Sunyoto. (2013). Metodologi Penelitian Akuntansi. (R. A. A. Ikapi, Ed.), Metodologi Penelitian Akuntansi. Bandung.

Ghozali, I. (2009). Aplikasi Multivariate dengan Program SPSS edisi III. Semarang: Badan Penerbit UNDIP. https://doi.org/10.1016/j.oooo.2017.11 .003

Ghozali, I. (2011). Aplikasi Analisi Multivariate dengan menggunakan SPSS. Gramedia.

Grega, M., \& Nemec, J. (2015). Factors Influencing Final Price of Public Procurement: Evidence from Slovakia. Procedia Economics and Finance, 25, 543-551.

https://doi.org/10.1016/S22125671(15)00768-6

Hanák, T., \& Muchová, P. (2015). Impact of Competition on Prices in Public Sector Procurement. In Procedia Computer Science (Vol. 64, pp. 729-735). https://doi.org/10.1016/j.procs.2015.08 .601

Hui, W. S., Othman, R., Omar, N. H., Rahman, R. A., \& Haron, N. H. (2011). Procurement issues in Malaysia. International Journal of Public Sector Management, 24(6), 567-593. https://doi.org/10.1108/095135511111 63666

Nash, C., \& Wolański, M. (2010). Workshop report - Benchmarking the outcome of competitive tendering. Research in Transportation Economics, 29(1), 610.

https://doi.org/10.1016/j.retrec.2010.0 7.003

Ohashi, H. (2009). Effects of transparency in procurement practices on government expenditure: A case study of municipal public works. Review of Industrial
Organization, 34(3), 267-285.

https://doi.org/10.1007/s11151-0099208-1

Republik Indonesia. (2000). Peraturan Pemerintah Nomor 29 Tahun 2000 tentang Penyelenggaraan Jasa Kontruksi. Sekretariat Negara. Jakarta

Republik Indonesia. (2006). Peraturan Pemerintah Nomor 6 Tahun 2006 tentang Pengelolaan Barang Milik Daerah. Jakarta

Republik Indonesia. (2007). Peraturan Presiden Nomor 106 Tahun 2007 tentang Lembaga Kebijakan Pengadaan Barang/ Jasa Pemerintah. Sekretariat Negara. Jakarta

Republik Indonesia. (2010). Peraturan Presiden Nomor 54 Tahun 2010 tentang Pengadaan Barang/ Jasa Pemerintah. Sekretariat Negara. Jakarta

Republik Indonesia. (2018). Peraturan Presiden Nomor 16 Tahun 2018 tentang Pengadaan Barang/ Jasa Pemerintah. Menteri Hukun dan HAM. Jakarta

Santoso, S. (2012). Panduan Lengkap SPSS Versi 20. (P. E. M. Komputido, Ed.). Jakarta.

Septyan, Budi. D., Putri, N.K. dan Arofah, T. (2015). Pengaruh Competitive Bidding Pada Pekerjaan Kontruksi Terhadap Penawaran Pemenang Tender Dalam E-Procurement LPSE PT. PLN (Persero). Jurnal Spektran, 15.

Simanjuntak, Timbul Hamonangan dan Mukhlis (2012), Dimensi Ekonomi Perpajakan dalam Pembangunan Ekonomi, Jakarta: Raih Asa Sukses.

Sugiyono, P. D. (2014). Populasi dan sampel. Metode Penelitian Kuantitatif, Kualitatif Dan $R \& D, 80$. 
Suliyanto. (2011). Ekonomika Terapan: Teori dan Aplikasi dengan SPSS. Yogyakarta: Offset, Andi CV.

Sutedi, A. (2010). Aspek Hukum Pengadaan Barang dan Jasa. (S. Grafika, Ed.). Jakarta.

Undang-undang Nomor 18 Tahun 1999 tentang Jasa Kontruksi. Indonesia

Undang-undang Nomor 1 Tahun 2004 tentang Perbendaharaan Negara. Indonesia

Walker, H., \& Brammer, S. (2012). The relationship between sustainable procurement and e-procurement in the public sector. International Journal of Production Economics, 140(1), 256268.

https://doi.org/10.1016/j.ijpe.2012.01.

008

https://jasp-stats.org/download/ 